spontaneous ascription is consistent with disagreement on the deep intuition on which that ascription is based, and with disagreement on other ascriptions of moral permissibility in other cases.

The present situation is analogous. Lowe and I agree in rejecting the spontaneous ascription of intentionality in the case at issue (understood on Lowe's terms). I reject it whilst retaining what I take to be our deep intuition concerning intentionality, namely that doing something is intentional if it is done because of an intention on the agent's part to do it. It is just that in this unusual case, the conditions in which the intuition is normally applied do not obtain, so that the spontaneous ascription based on this intuition is not here justified. Lowe rejects the spontaneous ascription, but also the deep intuition. He holds an account of intentionality which makes no reference to the agent's intentions. ${ }^{3}$ This account leads him to disagree with ascriptions of intentionality based on the deep intuition; for example, even with a general intention to kill Smith, Brown's killing is not intentional, but rather 'neither intentional nor unintentional'. ${ }^{4}$ This is not the place to discuss Lowe's general analysis of intentionality. It is enough to have shown that our spontaneous ascriptions of intentionality in Butler's problem can coherently be justified. Even where these ascriptions are not tenable, no doubt is cast on the soundness of that deep intuition, whose reflective application itself justifies their revision.

Sunderland Polytechnic, Chester Road,

(C) KIM DAVIES 1982 Sunderland SR1 3SD

\footnotetext{
${ }^{3}$ See E. J. Lowe, 'An Analysis of Intentionality', The Philosophical Quarterly, vol. 31, October 1981.

${ }^{4}$ Since writing this, Jonathan Lowe has told me of his uncertainty as to the application of his analysis to cases which involve these general intentions.
}

\title{
AGAINST A DEONTIC ARGUMENT FOR GOD'S EXISTENCE
}

\section{By PATRICK GRIM}

CARL R. KORDIG has recently presented the following two-part Aargument for the existence of God [4]:

$$
\text { I } \begin{aligned}
& \text { Og } \\
& \text { Og } \supset \diamond \mathrm{g} \\
\therefore & \diamond \mathrm{g} \\
\text { II } & \diamond \mathrm{g} \\
\therefore & \diamond \mathrm{g} \supset \square \mathrm{g} \\
\therefore & \square \mathrm{g}
\end{aligned}
$$


Here ' $g$ ' is to stand for 'God exists' and 'God' is to be defined as 'a most perfect being'.

Part II of Kordig's argument is a form of the ontological argument similar to that presented by Hartshorne [3] and Plantinga [5], [6]. But part I attempts to supply what many have thought has been crucially missing from ontological arguments - a supplementary argument for the possibility of God's existence. (See for example [1], [2], [8] and [9].) Kordig attempts to argue for the possibility of God's existence, moreover, on deontic grounds alone.

Kordig's deontic argument, however, suffers from the same general defect as its ontological predecessors: it fails to get off the ground.

Consider the first premise: 'Og', or 'It ought to be the case that God exists'. Kordig maintains that even atheists 'should grant that a perfect being ought to exist' (p. 207). But why? Surely one simple atheistic strategy would be to insist that it is not possible that God exists - just as the atheist has presumably maintained in the face of simpler ontological arguments - and to deny 'Og' on the grounds that it is not the case that the impossible ought to exist. One man's modus ponens is another man's modus tollens.

Let us put aside this standard objection, however, in order to concentrate on some major difficulties in the supplementary argument Kordig offers for his first premise:

Define God as a most perfect being. What is most perfect is, in particular, deontically perfect.... What is deontically perfect, ought to exist. Thus, God ought to exist. ([4]: p. 207).

How, in particular, are we to read the third sentence of this argument: 'What is deontically perfect, ought to exist'?

One plausible reading is this: that whatever is specified (or at least consistently specified) as deontically perfect ought to exist. But this would be an unacieptable principle. It would, to begin with, commit us to saying that each of a bizarre range of beings ought to exist: deontically perfect and polka dot beings, deontically perfect beings avidly devoted to stamp collecting, and so on. Such a principle would also lead to contradiction. For consider two purported beings, A and B. A is specified as the only deontically perfect being, as necessarily existent, and as blue. B is specified as the only deontically perfect being, as necessarily existent, and as non-blue. On the principle at issue, each of these ought to exist, since each is specified as deontically perfect. Since Op $\supset \diamond p$ for any $\mathrm{p}$, the existence of each is possible. But neither is contingent, so both must exist. Given our full specifications for A and B, however, both cannot exist.

If this is the reading intended in Kordig's argument for his first premise, then, that argument offers no reason for the atheist to embrace 'Og'. On this reading that argument relies on a principle which leads to contradiction, and so deserves to be rejected by theist and atheist alike. 
We might also offer a simpler reading for this crucial step in Kordig's argument for his first premise, however, which does not lead to contradiction: that it ought to be the case that a deontically perfect being exists, in the simple sense that there ought to be such a being.

There is a truth of deontic logic which is close to this, and which even the atheist cannot deny: that a deontically perfect situation or a deontically perfect world ought to exist. (There are serious difficulties with this notion, however: see [7].) Perhaps it can also be shown that a deontically perfect world must contain a deontically perfect being, and the atheist thus be forced to concede that there ought to be a deontically perfect being.

Would this be enough for Kordig's argument? No. That the argument requires more than merely deontic perfection is clear from the second step of the second part of the argument: $\diamond \mathrm{g} \supset \square \mathrm{g}$. Here Kordig says:

A most perfect being, however, is not contingent: $\sim(\diamond \mathrm{g} \& \diamond \sim \mathrm{g})$. For necessary existence is more perfect than contingent existence. Therefore, if it is logically possible that God exists, it is logically necessary that God exists: $\diamond \mathrm{g} \supset \square \mathrm{g} .([4]:$ p. 208)

The logic of the argument does not strictly demand that the being at issue be defined as 'most perfect', however. What is required is that $\mathrm{He}$ be deontically perfect - so as to lend plausibility to the first premise - and necessary, for the sake of ' $\diamond \mathrm{g} \supset \square \mathrm{g}$ '.

These two requirements, however - of deontic perfection and of alethic necessity of existence - appear to be logically distinct. Once the being at issue is specified not only as deontically perfect, then, but as necessary as well, the first premise becomes less than compelling and Kordig's argument for it becomes sadly incomplete.

The atheist, we will suppose, must concede that there ought to be a deontically perfect being. Must he also concede that there ought to be a deontically perfect and necessary being? Kordig offers no reason to think so, and the answer would appear to be 'no'. The atheist is no more forced to say that there ought to be a deontically perfect and necessary being, it appears, than he is forced to say that there ought to be a deontically perfect and polka-dot being, or a deontically perfect being who is also an avid stamp collector. Deontic perfection, after all, is perfection in terms of what is permissible and obligatory, and moral perfection is its prime exemplar. Existence in many possible worlds, or in all, does not itself seem to be anything like a moral virtue, and it does not appear that any being must fall short of moral perfection or anything like it - must fail to fulfil any duties, for instance, or must violate any rights or commit any wrongs - merely because that being is contingent.

The atheist's commitment to the claim that it ought to be the case that a deontically perfect being exists, then, does not appear to force him to accept ' $\mathrm{Og}$ ' in any sense that entails that a deontically 
perfect and necessary being exists, and thus does not appear to force him to accept ' $\mathrm{Og}$ ' in any sense full enough for the purposes of Kordig's argument as a whole.

On one interpretation of Kordig's argument for his first premise, that argument relies on a principle which leads to contradiction. On an alternative interpretation which avoids contradiction, the argument is sadly incomplete. I see no plausible reading of the argument, and no plausible argument to the same purpose, which avoids both of these flaws.

Kordig maintains that even atheists 'should grant a most perfect being ought to exist' (p. 207). Whatever its edificatory value, it does not appear that this 'should' has any important logical force. The atheist seems no more compelled to grant ' $O g$ ' than ' $\diamond \mathrm{g}$ ', and thus Kordig's deontic argument seems to offer no appreciable advance over its ontological predecessors.

State University of New York, at Stony Brook, NY 11794, U.S.A.

(C) PATRICK GRIM 1982

\title{
REFERENCES
}

[1] Patrick Grim, 'In Behalf of "In Behalf of the Fool"', forthcoming in International

[2] Joumal for Philosophy of Religion. 91-97.

[3] Charles Hartshorne, The Logic of Perfection (La Salle, Illinois, 1962).

44 Carl R. Kordig, 'A Deontic Argument for God's Existence', Nous, 15 (1981), $207-$ 208.

[5] Alvin Plantinga, God, Freedom, and Evil (New York: Harper and Row, 1974).

[6] The Nature Of Necessity (Oxford: Clarendon Press, 1974).

[7] Richard Purtill, 'Deontically Perfect Worlds and Prima Facie Obligations', Philosophia, 3 (1973), 429-438.

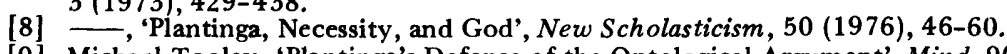

[9] Michael Tooley, 'Plantinga's Defense of the Ontological Argument', Mind, 90 (1981), 422-427.

\section{ON BEING A CAT}

\author{
By E. J. LOWE
}

$\mathrm{I}_{\mathrm{I}}^{\mathrm{N}}$ $\mathrm{N}$ 'The paradox of the 1,001 cats' (ANALYsis 42.1, January 1982), I argued that a lump of feline tissue $c$ could not be a cat, on the grounds that the sortal terms 'lump of feline tissue' and 'cat' have different criteria of identity associated with them. To this Professor P. T. Geach replied, in effect, that something may be a cat without necessarily complying with the criterion of identity associated with the sortal term 'cat' (ANALYSIS 42.1, January 1982). My objection 